\title{
Epidemiological and Etiological Aspects of Dental Caries Development
}

\author{
Galina Andriivna Loban', Mariia Oleksiivna Faustova, Victoriia Volodymyrivna Chereda, \\ Maiia Mykolaivna Ananieva
}

Ukrainian Medical Stomatological Academy, Poltava, Ukraine

\author{
SUMMARY
}

The infectious factor is etiological in the caries development. Early colonization of S.mutans is considered as a key point; another important caries-associated microorganism is Lactobacillus, which colonizes carious lesions later. Ecological shifts in the dental plaques against the background of weakened local immunity increase their cariogenicity and lead to the caries progression. The data obtained confirm the key importance of the oral colonization resistance in initiating dental caries and its progression.

Thus, the biological status of dental plaque and the activity of cariogenic bacteria are regarded as the key mechanisms for the emergence of dental caries. Therefore, the in-depth study of oral microbial homeostasis, the factors supporting its dynamic balance, is extremely important for modern cariology that will greatly contribute to developing programs and recommendations for prevention of dental caries and its early detection in order to improve the general health of population.

Key words: epidemiology of dental caries, etiology of dental caries, cariogenic microorganisms

Corresponding author:

Mariia O. Faustova

e-mail: masyanya.ne@gmail.com 


\section{INTRODUCTION}

Numerous reports demonstrate considerable improvement in the prevention of dental caries, which have been achieved over the last decades. Nevertheless, dental caries resulting in tooth loss when left untreated is still remaining the commonest dental problem worldwide. According to epidemiological studies, the prevalence of caries among the population of Ukraine reaches $80-100 \%$ in different age groups and shows no tendency to decline. Regular topical use of fluoride (e.g. fluoride-containing toothpastes) is considered to be the main breakthrough in maintaining oral health, as it has led to a sharp decrease in the prevalence of caries over the past decades of the XX century in western countries $(1,2)$. However, this method alone would not be enough to prevent caries occurrence in the presence of high-risk factors. There is still a pandemic prevalence of caries among populations around the world. It has been reported that in the EC in 2011, the treatment costs for dental caries made up 79 billion euros (3).

\section{The leading factors that determine the development of dental caries}

Dental caries is commonly described as a pathological process that may start developing after tooth eruption and causes demineralization and destruction of hard dental tissues with subsequent formation of tooth defects (holes) known as carious cavities. The generally known mechanisms of caries development are explained through the progressive demineralization of hard dental tissues of teeth under the influence of organic acids, whose formation is associated with functioning of certain microorganisms.

In the $50 \mathrm{~s}-60 \mathrm{~s}$ of the $20^{\text {th }}$ century, the level of sugar imports to the industrialized countries increased significantly, which contributed to a sharp increase in caries morbidity, especially in western countries. Meanwhile, over the past 30 years, highincome countries have considerably advanced in the prevention of dental caries, especially among children and adolescents. The main reason for this success was the wide-scale use of fluoride-containing products. The reduction of caries prevalence among children was achieved most likely due to the availability of children's fluoride-containing toothpaste, improved oral care instructions and self-care practices along with some other factors (4).
However, despite the importance of the measures taken, since 1995, the rate of caries decline has been slowed down considerably. Nowadays, dental caries is still being a dramatical health challenge: almost all adult and child population worldwide is exposed to this disease $(3,5)$. In high income countries, dental caries has transitioned into a socially-conditioned disease (6).

The prevalence of dental caries in children and adolescents considerably depends on social and economic factors, including the education background of parents as well as their income level. In the underprivileged groups of population, dental caries is reported as more commonly diagnosed. A higher educational level and higher income of parents is associated with a low prevalence of dental caries (6).

The study of the quantitative relationship between sugar intake and the progression of dental caries in children with different susceptibility to caries has shown that the disease arose both in children who had been identified as more caries-resistant and in children identified as caries-susceptible, when even their sugar consumption made up only 2 - 3\% of the energy consumed, provided that the teeth had been exposed to sugars for more than three years. Despite the increasing enamel resistance after eruption, throughout the rest of life, there was a progressive linear increase in dental carious lesions that can explain higher caries indices in adults than in children (7).

Thus, the provisional conclusions regarding the sugar consumption by children have misled public health. The recommendations that sugar consumption should be $\leq 10 \%$ of the total energy consumed are no longer acceptable. A much greater burden of caries in adults emphasizes the importance for very low sugar intake throughout life. Adults are more susceptible to dental caries, and therefore they need to reduce their daily intake of sugar to $2-3 \%$ of the total energy they consume, regardless of whether they get enough fluoride or not (7).

One of the leading factors that determine the development of a carious progression is oral hygiene. Poor oral hygiene has been proven as a major risk factor contributing to the oral health deterioration (8).

Low oral hygiene is known as a critical local cariogenic factor starting up through the increase of 
microbial burden and reduction of oral colonization resistance (9).

It has been demonstrated that the infectious factor is etiological in the caries occurrence and progression. All others (general and local), and namely environmental factors, psycho-emotional stress, the presence of somatic pathology, insufficient enamel mineralization, chemical composition of saliva, and sweet food can be classified as contributory ones (1). The cariogenic effect produced by oral microorganisms is noticeable when they have built up a dental biofilm.

\section{Role of normal microbiota in the development of dental caries}

Dental plaque (biofilm) is one of the most essential risk factors or the trigger mechanism for the emergence of dental caries occurrence. Cariogenic microorganisms of dental plaque in the presence of an excess of carbohydrates taken with food produce organic acids and can cause caries development. In individuals with high caries intensity (DMFT $\geq 6$ ), Greene-Vermillion index (oral hygiene index) is as 3.4 times higher, and interdental hygiene index is by $12 \%$ lower than in those with intact hard dental tissues. The sex and caries distribution confirmed this pattern found in both men and women. The correlation between the average strength of hygienic indices and the level of caries intensity has been reported (2).

Normal microbiota plays an important role in optimal body functioning. One of its most important functions is to ensure with the host body the colonization resistance to a macroorganism. The composition of normal microbiota, the stability of its composition and physiological functions are supported by complex mechanisms of symbiosis with the microorganism and were formed through the process of long coexistence in the form of a unified biocenosis $(10-12)$.

The data obtained affirm the key importance of the oral colonization resistance in initiating dental caries and its progression. In order to make the early diagnosis of oral colonization resistance imbalance and thus to predict possible caries development as a consequence of this imbalance, the screening program to assess the oral mucosa colonization resistance has already been proven very effective for a wider application (13). The planning of prophylactic programs should take into account the status of oral coloniza- tion resistance as a risk factor for the development of dental caries.

The progression of dental caries results in considerable changes in quantitative and qualitative values of the oral fluid microflora composition. Growing intensity of dental caries is accompanied by an increase in the frequency and density of colonization with cariogenic and opportunistic microflora (2).

Dental caries is reported as one of the most prevalent chronic diseases of dietary-bacterial aetiology. Caries is characterized by biological shift in the environment of dental biofilms due to frequent intakes of dietary carbohydrates, which are easily fermentable ones. This leads to the transition from a well-balanced population of microorganisms with low cariogenicity to the growth of microbiological population with a high cariogenicity (acidophilic and acidogenic) and as a result to the increased formation of organic acids. The acid formation close to dental structures causes demineralization of enamel and dentin (14).

Modern concepts consider dental caries as a complex interaction between biological, social, behavioral and psychological factors, where dental biofilm is as a key element. Long-term diet rich in easily fermentable carbohydrates as well as long-lasting and frequent exposures of dental surfaces to acids lead to the shift when more acidophilic microorganisms become dominant due to acid-induced selection (15). Early exposure to $S$. mutans is considered as one of the critical elements in the development of early childhood caries and a predicted factor for adult caries. Another essential caries-associated microorganism is Lactobacillus colonizing carious lesions later than $S$. mutans (16). Otherwise, the presence of some bacterial species in the dental biofilm, such as S. sanguinis, S.salivarius, S.mitis and other Streptoccus spp. as well as Lactobacillus spp. can slowly promote progression of dental caries in children (17).

\section{Dental caries in cases of type 2 diabetes}

The correlation between oral health and type 2 diabetes has also been well known $(18,19)$. Unbalanced diabetes mellitus is associated with significant cariogenic changes in the oral cavity, including unstimulated and stimulated saliva, lowering its buffering capacity and $\mathrm{pH}$ shifting towards the acidic side, higher concentrations of glucose and albumin in saliva, high levels of $S$. mutans and yeast $(20,21)$. 
Changes in the oral microflora in diabetics with poor glycemic control can significantly affect the prevalence of dental caries $(22,23)$. However, contrary to the preliminary conclusion, Tagelsir A et al. noted a lower caries level in children with type 1 diabetes. Children and adolescents with type 1 diabetes demonstrated high sensitivity to dental caries under poor metabolic control $(24,25)$.

Individuals with diabetes showed a higher level of cariogenic bacteria (S. mutans, S. sobrinus, L.fermentum, S.salivarius, L.salivarius) compared to non-diabetic children. There have been found out statistically significant differences between individuals with diabetes who adhered to strict metabolic control and those who did not in relation to certain cariogenic bacteria (S. mutans, S. soubrinus, L.casei, L.fermentum, S. sialivarius). Non-essential cariogenic strains showed no statistically significant differences in the two groups studied. Only S.salivarius was found to show statistically significant differences between the individuals with and without diabetes $(p=0.03)$, between those with poor metabolic control and those who did not have diabetes $(\mathrm{p}<0.01)$ and between patients with diabetes who adhered to adequate metabolic control and those who did not ( $p$ $=0.04)(26)$.

\section{The modern view on the aetiology of dental caries}

Microorganisms isolated from carious lesions in individuals with acute deep caries by using the automatic bacteriological analyzer Vitec-2 Systems bioMérieux (France) and data on the peculiarities of their biochemical properties suggest that Kocuria rosae, Kocuria kristinae, Leuconostoc mesenteroides are parts of the microflora of carious lesions in acute deep caries of I, II classes by G. V. Black classification and can be involved into the development of the caries progression $(27,28)$.

It has been found out that the microorganisms are characterized by different affinities, even to different tooth surfaces. Moreover, the process of adhesion is also influenced by mechanical factors associated with chewing, oral physical and chemical conditions, etc. Therefore, on different surfaces of teeth, pits and fissures, the composition of the microflora is slightly different even within one tooth (29).

After consuming food, especially rich in carbo- hydrates, the enzymatic activity of bacteria is sharply increased in the oral liquid - there is so-called a "metabolic explosion". The «metabolic explosion" is driven by the activation of glycolysis that leads to a sharp shift in the $\mathrm{pH}$ towards the acid side due to the release of acidic metabolites - acetic, pyruvic and other acids. In turn, this leads to the release of calcium ions from the hard dental tissues as well as to the decrease in phosphate content during phosphorylation in bacteria. In addition, bacteria in the dental plaques accumulate an excess of carbohydrates in the form of reserve polysaccharides, dextran and levans. Due to the dominance of $S$. mutans, lactobacilli and actinomycetes in patients with dental caries, the production of organic acids becomes higher, while the normalization of metabolic activity gets slower. $S$. mutans plays the main role in the initial stages of the caries development, and under the further exposure of dentin during the caries progression the number of lactobacilli increases and their pathogenic role enhances (30).

Over the recent years, the number of studies has confirmed the role of some residents participating in the microbiocenosis of the dental plaque as antagonists to cariogenic streptococci. First of all, this concerns veillonella, gram-negative anaerobic cocci, which actively utilize acids. This allows us to consider the veillonella as the most essential microbiotic factor of caries resistance.

Although pathogenic bacteria are easily transmitted, caries is fairly considered a multifactorial disease. The specific composition of the biological film and its metabolic activity depends on the current combination of several different factors: the composition and consistency of saliva, the composition of foods, the functioning of the systemic and local immunity, as well as the $\mathrm{pH}$ value and concentration of fluorine ions in the biological film, saliva or gingival sulcus secretion. The interaction between all these heterogeneous factors ultimately determines the probability and rate of hard dental tissue demineralization.

The modern view on the aetiology of dental caries mostly agrees with the "hypothetical ecological situation in dental plaque", developed by O. Fejerskov in 2004. According to this concept, the implementation of cariogenicity by dental plaque, i.e. triggering the dental enamel demineralization (initial caries), is only possible in unfavorable and stressful conditions, for example, when taking excess sweets (30). Under fa- 
vorable conditions, the dental plaque environment changes in the better way and the risk of caries reduces (31).

Dental caries should be identified as an infectious process initiated by a specific microflora of the dental biofilm that ferment dietary carbohydrates followed by the acid formation. In order for these microorganisms to show their aggressive properties to the full, there is a large number of systemic and local risk factors that create conditions necessary for the caries development. At present, one of the most important immunological factors that predetermine the oral immunity is specific protective factors. Oral homeostasis, including the balanced content of the normal and opportunistic microflora, is provided by factors of mucosal immunity, where secretory immunoglobulin of class A (sIgA) plays an important role. According to literature data, there is a tendency towards a decrease in the level of sIgA in the oral fluid in individuals with high caries intensity indices $(32,33)$.

\section{CONCLUSION}

Thus, dental caries should be seen as a multifactorial disease (along with cardiovascular diseases, cancer, diabetes, etc.), which is triggered by the interaction of many genetic, ecological and behavioural risk factors. It is necessary to emphasize that biological status of dental plaque and the activity of cariogenic bacteria are regarded as the key mech-anisms for the emergence of dental caries. Therefore, the indepth study of oral microbial homeostasis, ie. the factors supporting its dynamic balance, is extremely important for modern cariology that will greatly contribute to developing programs and recommendations for the prevention of dental caries and its early detection in order to improve general health of population.

\section{Conflict of interest}

The authors state no conflict of interest.

\section{References}

1. Sun L, Wong HM, McGrath CPJ. The factors that influence oral health-related quality of life in young adults. Health Qual Life Outcomes 2018;16(1): 187.

https://doi.org/10.1186/s12955-018-1015-7

2. Petrushanko TA, Chereda VV, Loban' GA. The relationship between colonization resistance of the oral cavity and individual-typological characteristics of personality: dental aspects. Wiadomosci Lekarskie 2017;70(4):754-7.
3. Rugg-Gunn A. Dental caries: strategies to control this preventable disease. Acta Medica Academica 2013;42(2):117-30. https://doi.org/10.5644/ama2006-124.80

4. Davies GM, Neville J, Jones K, White S. Why are caries levels reducing in five-year-olds in England? Br Dent J 2017;223(7):515-9. https://doi.org/10.1038/sj.bdj.2017.836

5. Casamassimo PS, Thikkurissy S, Edelstein BL, 
Maiorini E. Beyond the dmft: the human and economic cost of early childhood caries. J Am Dent Ass 2009;140:650-7.

https://doi.org/10.14219/jada.archive.2009.0250

6. Kato H, Tanaka K, Shimizu $\mathrm{K}$ et al. Parental occupations, educational levels, and income and prevalence of dental caries in 3-year-old Japanese children. Environ Health Preven Med 2017;22(1):80. https://doi.org/10.1186/s12199-017-0688-6

7. Sheiham A, James WP. A new understanding of the relationship between sugars, dental caries and fluoride use: implications for limits on sugars consumption. Public Health Nutr 2014;17(10):217684.

https://doi.org/10.1017/S136898001400113X

8. Sun HB, Zhang W, Zhou XB. Risk Factors associated with Early Childhood Caries. Chin J Dent Res 2017;20(2):97-104.

9. Drachev SN, Brenn T, Trovik TA. Oral HealthRelated Quality of Life in Young Adults: A Survey of Russian Undergraduate Students. Int J Environ Res Public Health 2018;15(4). pii: E719. https://doi.org/10.3390/ijerph15040719

10. Rosier BT, Marsh PD, Mira A. Resilience of the Oral Microbiota in Health: Mechanisms That Prevent Dysbiosis. J Dent Res 2018; 97(4):371-80. https://doi.org/10.1177/0022034517742139

11. Zaura E, Keijser BJ, Huse SM, Crielaard W. Defining the healthy "core microbiome" of oral microbial communities. BMC Microbiol 2009;9:259. https://doi.org/10.1186/1471-2180-9-259

12. Zaura E, Nicu EA, Krom BP, Keijser BJF. Acquiring and maintaining a normal oral microbiome: current perspective. Front Cell Infect Microbiol 2014;4:85.

https://doi.org/10.3389/fcimb.2014.00085

13. Petrushanko TA, Chereda VV, Loban' GA. [Role of oral cavity colonization resistance in dental caries development]. Stomatologiia 2013;92(1):43-5.

14. Tanner ACR, Kressirer CA, Rothmiller S, Johansson I, Chalmers NI. The Caries Microbiome:
Implications for Reversing Dysbiosis. Adv Dent Res 2018;29(1):78-85.

https://doi.org/10.1177/0022034517736496

15. Takahashi N, Nyvad B. The role of bacteria in the caries process: ecological perspectives. J Dent Res 2011;90(3):294-303.

https://doi.org/10.1177/0022034510379602

16. Mitrakul K, Asvanund Y, Vongsavan K. Prevalence of five biofilm-related oral streptococci species from plaque. J Clin Pediatr Dent 2011;36(2):161-6. https://doi.org/10.17796/jcpd.36.2.d7r750u227j85813

17. Mitrakul K, Vongsavan K, Suratanachaikul P. Prevalence of Streptococcus mutans and Lactobacillus fermentum and their association with caries and dietary habits in preschool Thai children. Eur Arch Paediatr Dent 2013;14(2):83-7. https://doi.org/10.1007/s40368-013-0017-8

18. Aitken-Saavedra J, Rojas-Alcayaga G, MaturanaRamirez A et al. Salivary gland dysfunction markers in type 2 diabetes mellitus patients. J Clin ExpDent 2015;7(4):e501-5.

https://doi.org/10.4317/jced.52329

19. Leite RS, Marlow NM, Fernandes JK. Oral health and type 2 diabetes. Am JMed Sci 2013;345(4):2713.

https://doi.org/10.1097/MAJ.0b013e31828bdedf

20. Negrato CA, Tarzia O. Buccal alterations in diabetes mellitus. Diabetol Metab Syndr 2010;2:3 https://doi.org/10.1186/1758-5996-2-3

21. Rai K, Hegde AM, Kamath A, Shetty S. Dental caries and salivary alterations in Type I Diabetes. J Clin Pediatr Dent 2011;36(2):181-4. https://doi.org/10.17796/jcpd.36.2.x436ln878221g364

22. Miko S, Ambrus SJ, Sahafian S, Dinya E, Tamas G, Albrecht MG. Dental caries and adolescents with type 1 diabetes. Br Dent J 2010;208(6):E12 https://doi.org/10.1038/sj.bdj.2010.290

23. Saes Busato IM, Bittencourt MS, Machado MAN, Gregio AMT, Azevedo-Alanis LR. Association between metabolic control and oral health in adolescents with type 1 diabetes mellitus. Oral 
Surg Oral Med Oral Pathol Oral Radiol Endodontics 2010;109(3):e51-6. https://doi.org/10.1016/j.tripleo.2009.10.037

24. Tagelsir A, Cauwels R, van Aken S, Vanobbergen J, Martens LC. Dental caries and dental care level (restorative index) in children with diabetes mellitus type 1. Int J Paediatr Dent 2011;21(1):13-22. https://doi.org/10.1111/j.1365-263X.2010.01094.x

25. Akpata ES, Alomari Q, Mojiminiyi OA, Al-Sanae $\mathrm{H}$. Caries experience among children with type 1 diabetes in Kuwait. Pediatr Dent 2012;34(7):468-72.

26. Lai S, Cagetti MG, Cocco F, Cossellu D, Meloni G, Campus G, Lingström P. Evaluation of the difference in caries experience in diabetic and non-diabetic children-A case control study. PLoS One 2017;12(11):e0188451 https://doi.org/10.1371/journal.pone.0188451

27. Ananieva MM, Faustova MO, Basarab IO, Loban' GA. Kocuria rosea, Kocuria kristinae, Leuconostoc mesenteroides as caries-causing representatives of oral microflora. Wiadomosci Lekarskie 2017;70(2):296-8.

28. Ananieva M, Nazarchuk O, Faustova M, Basarab Y, Loban G. Pathogenicity factors of kocuria kristinae contributing to the development of periimplant mucositis. Malaysian J Med Health Sci 2018; 14 (3): 34-8.

29. Faustova MO, Ananieva MM, Basarab YO, Dobrobolska OV, Vovk IM, Loban' GA. Bacterial factors of cariogenicity (literature review). Wiadomosci Lekarskie 2018;71(2 pt 2):378-382.

30. Takahashi N, Nyvad B: Caries ecology revisited: microbial dynamics and the caries process. Caries Res 2008;42:409-18. https://doi.org/10.1159/000159604

31. Devine DA, Marsh PD, Meade J: Modulation of host responses by oral commensal bacteria. J Oral Microbiol 2015;7:26941.

https://doi.org/10.3402/jom.v7.26941

32. Petrushanko TA, Tchereda VV, Loban GA. [The screening diagnostic of micro ecological disorders of oral cavity]. Klinicheskaiia Laboratornaiia Diagnostika 2014;(6):48-50.

33. Faustova MO, Ananieva MM, Basarab YO, Loban' GA. Neutrophil bactericidal activity through the stages of placement of different dental implants depending on their chemical composition. Wiadomosci lekarskie 2017:70 (5):921-4. 


\title{
Epidemiološki i etiološki aspekti razvoja zubnog karijesa
}

\author{
Galina Andriivna Loban', Mariia Oleksiivna Faustova, Victoriia Volodymyrivna Chereda, \\ Maiia Mykolaivna Ananieva \\ Ukrajinska medicinsko-stomatološka akademija, Poltava, Ukrajina
}

SAŽETAK

Infektivni faktor je etiološke prirode u razvoju karijesa. Rana kolonizacija S.mutans smatra se ključnim momentom; drugi važan mikroorganizam za razvoj karijesa je Lactobacillus, koji kolonizuje karijesne lezije nešto kasnije. Ekološke promene u zubnim naslagama u pozadini oslabljenog lokalnog imuniteta povećavaju njegovu kariogenost i dovode do razvoja karijesa. Dobijeni podaci potvrđuju ključni značaj rezistencije usne duplje na kolonizaciju za nastanak zubnog karijesa i njegovo napredovanje.

Stoga se biološki status zubnog plaka i aktivnost kariogenih bakterija smatraju ključnim mehanizmima u razvoju zubnog karijesa. Detaljno ispitivanje oralne mikrobiološke homeostaze, faktora koji podržavaju njen dinamički balans, od izuzetnog je značaja za savremenu kariologiju, koja će u velikoj meri doprineti razvoju programa i preporuka za prevenciju zubnog karijesa i njegovo rano otkrivanje $u$ cilju poboljšanja opšteg zdravstvenog stanja stanovništva.

Ključne reči: epidemiologija zubnog karijesa, etiologija zubnog karijesa, kariogeni mikroorganizmi 